\title{
Sporulation of Fusarium oxysporum f. sp. lycopersici on Stem Surfaces of Tomato Plants and Aerial Dissemination of Inoculum
}

\author{
Talma Katan, E. Shlevin, and J. Katan
}

First author: Department of Plant Pathology, ARO, The Volcani Center, P.O. Box 6, Bet Dagan 50250, Israel; and second and third authors: Department of Plant Pathology and Microbiology, The Hebrew University of Jerusalem, Faculty of Agricultural, Food, and Environmental Quality Sciences, Rehovot 76100, Israel. Accepted for publication 27 March 1997.

\section{ABSTRACT}

Katan, T., Shlevin, E., and Katan, J. 1997. Sporulation of Fusarium oxysporum f. sp. lycopersici on stem surfaces of tomato plants and aerial dissemination of inoculum. Phytopathology 87:712-719.

Plants exhibiting symptoms of wilt and xylem discoloration typical of Fusarium wilt caused by Fusarium oxysporum f. sp. lycopersici were observed in greenhouses of cherry tomatoes at various sites in Israel. However, the lower stems of some of these plants were covered with a pink layer of macroconidia of $F$. oxysporum. This sign resembles the sporulating layer on stems of tomato plants infected with $F$. oxysporum $\mathrm{f}$. sp. radicis-lycopersici, which causes the crown and root rot disease. Monoconidial isolates of $F$. oxysporum from diseased plants were assigned to vegetative compatibility group 0030 of $F$. oxysporum f. sp. lycopersici and identified as belonging to race 1 of $F$. oxysporum $\mathrm{f}$. sp. lycopersici. The possibility of coinfection with $F$. oxysporum f. sp. $l y$ copersici and $F$. oxysporum f. sp. radicis-lycopersici was excluded by testing several macroconidia from each plant. Airborne propagules of $F$. oxysporum f. sp. lycopersici were trapped on selective medium in greenhouses in which plants with a sporulating layer had been growing. Sporulation on stems was reproduced by inoculating tomato plants with races 1 and 2 of $F$. oxysporum $\mathrm{f}$. sp. lycopersici. This phenomenon has not been reported previously with $F$. oxysporum f. sp. lycopersici and might be connected to specific environmental conditions, e.g., high humidity. The sporulation of $F$. oxysporum $\mathrm{f}$. sp. lycopersici on plant stems and the resultant aerial dissemination of macroconidia may have serious epidemiological consequences. Sanitation of the greenhouse structure, as part of a holistic disease management approach, is necessary to ensure effective disease control.
In many growing regions of the world, tomatoes (Lycopersicon esculentum Mill.) are attacked by two subspecific taxa of Fusarium oxysporum: F. oxysporum Schlechtend.:Fr. f. sp. lycopersici (Sacc.) W.C. Snyder \& H.N. Hans., the incitant of Fusarium wilt, and $F$. oxysporum f. sp. radicis-lycopersici W.R. Jarvis \& Shoemaker, the incitant of Fusarium crown and root rot. The two pathogens differ in the symptoms they cause, their epidemiology, and the cultivars they affect $(1,16,18,29)$. In particular, the crown and root rot pathogen forms a sporulating layer of conidia on tomato stems, and the conidia become airborne and disseminate in the greenhouse $(16,30)$. As in many countries, Fusarium wilt of tomatoes in Israel has become rare, because of the introduction of cultivars that are resistant to both races 1 and 2 of $F$. oxysporum $\mathrm{f}$. sp. lycopersici. Race 3, which can attack these cultivars, has never been recorded in Israel. However, following the recent introduction to Israel of cherry tomato cultivars that lack genes for resistance, the occasional reappearance of Fusarium wilt, incited primarily by race 1 , has been observed. In contrast to Fusarium wilt, Fusarium crown and root rot of tomatoes is widespread in Israel, mainly in winter crops, because resistant cultivars are not widely used. Tomato fields are monitored routinely by our group for the possible appearance of race 3 of $F$. oxysporum $\mathrm{f}$. sp. lycopersici, as well as to study population dynamics of $F$. oxysporum f. sp. radicis-lycopersici (20). Although physiological races have not been recognized in $F$. oxysporum f. sp. radicis-lycopersici, genetic diversity of this pathogen has been demonstrated by the existence of several vegetative compatibility groups (VCGs) (25). Vegetative compatibility (heterokaryon) testing, in

Corresponding author: T. Katan; E-mail address: vpptlg@volcani.agri.gov.il

Publication no. P-1997-0508-01R

(C) 1997 The American Phytopathological Society parallel with pathogenicity testing, using nitrate nonutilizing (nit) mutants has proven highly reliable for distinguishing among formae speciales of $F$. oxysporum, in general, and between $F$. oxysporum $\mathrm{f}$. sp. lycopersici and $F$. oxysporum $\mathrm{f}$. sp. radicis-lycopersici, in particular $(8,25)$.

In 1992, an unusual phenomenon was observed in a greenhouse of cherry tomatoes in Israel. Wilting plants exhibited xylem discoloration throughout the upper stems, which is a typical symptom of Fusarium wilt disease. On the other hand, the lower stems of many of these plants were covered with a sporulating layer of macroconidia typical of crown and root rot disease. This new combination of symptoms could have resulted from several causes: (i) coinfection of plants by the two $F$. oxysporum pathogens, especially since both had been recorded in this greenhouse in previous years; (ii) the sporulation of $F$. oxysporum $\mathrm{f}$. sp. lycopersici on a specific cultivar or under specific conditions; or (iii) a variant of $F$. oxysporum f. sp. radicis-lycopersici or $F$. oxysporum f. sp. lycopersici. In this work, we studied the nature of the F. oxysporum pathogen(s) forming the sporulating conidial layer on tomato stems, along with some epidemiological aspects related to dissemination. A preliminary report on this study has been published (24).

\section{MATERIALS AND METHODS}

Media. Potato dextrose agar (PDA) and modified peptonepentachloronitrobenzene Fusarium-selective medium (FSM) (32) were used to isolate fungi from diseased plants. FSM also was used to enumerate Fusarium propagules. Czapek-Dox medium (CDM) (32) was used to grow inoculum for pathogenicity testing. A sucrose-salt medium that contained nitrate as the nitrogen source, Puhalla's (27) minimal medium (MM), was used to recognize nit mutants and for complementation (heterokaryon) tests. Chlorate media, based on MM or PDA amended with potassium chlorate, were used to select nit mutants (6). 
Reference strains. The following pathogenic strains of $F$. $o x$ ysporum were used as references in pathogenicity tests: f. sp. lycopersici isolates FOL-1 (ATCC 66044, race 1) and FOL-1295 (ATCC 66047, race 2) (9); and f. sp. radicis-lycopersici isolate FORL-CRNK78 (25). In vegetative compatibility tests, the following nit mutants were used as testers: f. sp. lycopersici strains FOL-M and FOL-R of VCG 0030, the only VCG found in Israel $(9,21)$; and 16 mutants (eight pairs) representing the five local VCGs of f. sp. radicis-lycopersici and subgroups thereof (25).

Pathogen isolation. $F$. oxysporum was isolated from upper stem tissues exhibiting vascular discoloration and from the sporulating layer on the surfaces of lower stems. Colonies of $F$. oxysporum, obtained from upper stem tissues on FSM as described (14), were identified morphologically. One monoconidial isolate per plant was then prepared for vegetative compatibility and pathogenicity testing. Macroconidia from the sporulating layer on the lower stems were suspended in loopfuls of sterile water, streaked over PDA, and incubated overnight at 24 to $25^{\circ} \mathrm{C}$. Germinating macroconidia were transferred individually to PDA plates and used for vegetative compatibility and pathogenicity testing.

Pathogenicity and race determination. Isolates of $F$. oxysporum were grown on $\mathrm{CDM}$ at $27^{\circ} \mathrm{C}$ for 7 to 9 days. The contents of each petri dish $(9 \mathrm{~cm}$ in diameter) were macerated with 75 $\mathrm{ml}$ of water to prepare an inoculum suspension (ranging from 0.5 $\times 10^{6}$ to $2 \times 10^{6}$ conidia/ml). Tomato cultivars Marmande (susceptible to races 1 and 2) and Rehovot 13 (resistant to race 1 and susceptible to race 2) were used for testing Fusarium wilt pathogenicity and race identification. Seedlings were uprooted from the soil 8 days after sowing. Their roots were washed free of soil and dipped in inoculum suspension for $2 \mathrm{~min}$. Seedlings were then transplanted (seven per pot) to $700-\mathrm{ml}$ pots filled with Rehovot sandy soil $(3.8 \%$ clay, $0.0 \%$ silt, $96.2 \%$ sand, and $0.4 \%$ organic matter; $\mathrm{pH}$ 6.9). The soil was free of $F$. oxysporum $\mathrm{f}$. sp. lycopersici or other known pathogens prior to planting, as evidenced by planting with noninoculated melon, tomato, and eggplant seedlings. The inoculated seedlings were maintained in the greenhouse at 25 to $28^{\circ} \mathrm{C}$ in natural daylight. Seedlings showing typical disease symptoms such as wilt, xylem discoloration, and stunting were recorded for 21 days. Noninoculated tomato seedlings, maintained under the same conditions and serving as controls, showed no disease symptoms. Seedlings inoculated with reference isolates of races 1 and 2 were grown under the same conditions. Fusarium crown and root rot pathogenicity was tested as described (25) using 16-day-old seedlings of 'Rehovot 13'. The inoculated seedlings were maintained in the greenhouse at 20 to $24^{\circ} \mathrm{C}$, and symptoms of collapse or brown lesions on the roots were recorded for 21 days.

Vegetative compatibility tests. Vegetative compatibility between $F$. oxysporum isolates and the testers of $F$. oxysporum $\mathrm{f}$. sp. lycopersici and $F$. oxysporum f. sp. radicis-lycopersici was determined by complementation (heterokaryon) tests on MM using nit mutants (6). When a nit mutant formed wild-type heterokaryotic growth at the contact zone with testers FOL-R, FOL-M, or both, its parent isolate was regarded as belonging to VCG 0030 of $F$. oxysporum f. sp. lycopersici; when a similar interaction occurred between a mutant and any pair of testers of $F$. oxysporum f. sp. radicis-lycopersici, its parent isolate was assigned to the corresponding VCG of this pathogen (25); and when complementary mutants did not show complementation with any of the testers, their parent isolate was regarded as neither f. sp. lycopersici nor f. sp. radicis-lycopersici. This method served as the principal diagnostic test, confirmed by pathogenicity tests of representative isolates.

Enumeration of conidia from the stem surface. Stems covered with masses of Fusarium conidia, as verified by microscopic examination, were cut into $1-\mathrm{cm}$ segments that were then shaken in $5 \mathrm{ml}$ of sterile water for $1 \mathrm{~min}$ with a vortex mixer. The resulting conidial suspension was transferred to a conical flask containing $20 \mathrm{ml}$ of sterile water. Flasks were shaken for $30 \mathrm{~min}$ in a reciprocal shaker (200 strokes/min), and conidia were counted directly in the suspension with a hemacytometer cell. Results were expressed as the number of conidia per centimeter of stem. Viability of conidia was tested by spreading $0.1-\mathrm{ml}$ suspension samples on FSM and determining percent germination after overnight incubation at $25^{\circ} \mathrm{C}$.

Enumeration of $F$. oxysporum and $F$. oxysporum f. sp. lycopersici in rhizosphere soil. Samples of rhizosphere soil were obtained from three sampling points, and the number of colonyforming units (CFU) of $F$. oxysporum per gram of soil was determined by the soil-dilution method (14). To determine the proportion of $F$. oxysporum f. sp. lycopersici colonies, representative colonies were subcultured without single-sporing on CDM for vegetative compatibility and pathogenicity testing.

Scanning electron microscopy. Stem pieces covered with macroconidia were fixed with $5 \%$ glutaraldehyde in $0.1 \mathrm{M}$ phosphate buffer saline for $2 \mathrm{~h}$, rinsed twice with the same buffer, dehydrated by immersing twice in $50 \%$ ethanol for $30 \mathrm{~min}$, and then immersing overnight in $100 \%$ ethanol. The specimens were critical-point dried, coated with gold, and examined with a JEOL JSM-35 scanning electron microscope (JEOL Ltd., Tokyo).

Trapping of airborne propagules. The occurrence of airborne propagules of $F$. oxysporum was assessed in three commercial greenhouses of cherry tomatoes as described by Gamliel et al. (14). FSM plates were placed on stands $15 \mathrm{~cm}$ above the ground (10 plates in each of five or nine spans in each greenhouse), exposed for $60 \mathrm{~min}$ in the morning, and then incubated at $27^{\circ} \mathrm{C}$ for 7 days. Colonies exhibiting $F$. oxysporum morphology were counted, and representatives were subcultured without single-sporing on CDM for vegetative compatibility and pathogenicity testing.

Propagules of $\boldsymbol{F}$. oxysporum on strings and walls. Plastic strings hanging in various locations in the greenhouse were cut into 5-cm segments. Each segment was cut into 15 to 20 pieces, which were then scattered over FSM and incubated at $27^{\circ} \mathrm{C}$ for 7 days. The number of $F$. oxysporum colonies growing from the string pieces was counted, and representative colonies were subcultured without single-sporing on CDM for vegetative compatibility and pathogenicity testing. Results were expressed as number of colonies of $F$. oxysporum or $F$. oxysporum $\mathrm{f}$. sp. lycopersici per $1 \mathrm{~cm}$ of string. Contamination of the walls by Fusarium was assessed by wiping the surface with sterile wet cotton swabs and blotting on FSM as described previously (14). Representative colonies of $F$. oxysporum were subcultured on CDM for vegetative compatibility and pathogenicity testing.

Simulation of conidiation on stems of tomatoes and other crops under greenhouse conditions. Mild plant inoculation was carried out with transplants rather than seedlings in order to obtain disease symptoms at the age of 2 to 3 months, similar to those that occur under natural infections. Thirty-day-old transplants of the indicated cultivars of tomato and of eggplant (Solanum melongena L. 'Black Beauty') were obtained from a commercial nursery and planted in 4-liter plastic buckets filled with Rehovot soil (one plant per bucket). Plants were inoculated 15 days later by pouring $5 \mathrm{ml}$ of the indicated concentration of inoculum suspension in each of four 3-cm-deep holes around each plant at a distance of 5 $\mathrm{cm}$. Tomato plants were inoculated $\left(10^{5} \mathrm{conidia} / \mathrm{ml}\right)$ with the indicated isolates and races, and eggplants were inoculated with $F$. oxysporum f. sp. melogenae Matuo \& Ishigami (isolate FOMG$690 \mathrm{~B} ; 2.5 \times 10^{5}$ conidia/ml). Seeds of muskmelon (Cucumis melo L. 'Ananas-Ein-Dor'), cucumber (Cucumis sativus L. 'Delila'), and cotton (Gossypium barbadense L. 'Pima S-5') were sown directly in buckets and later thinned to one plant per bucket. They were similarly inoculated 40 days after planting with $F$. oxysporum $\mathrm{f}$. sp. melonis W.C. Snyder \& H.N. Hans. (isolate FOM-ARV4, race $0 ; 3 \times 10^{5}$ conidia/ml), F. oxysporum f. sp. cucumerinum J.H. Owen (isolates FOCU-27D and FOCU-49R; $4 \times 10^{5}$ conidia/ml), and $F$. oxysporum f. sp. vasinfectum (Atk.) W.C. Snyder \& H.N. Hans. (isolate FOV-FIL6, race 3; $3 \times 10^{5}$ conidia/ml), respec- 
tively. Seeds of chickpea (Cicer arietinum L. 'Bulgarit') were seeded directly in a field soil naturally infested with $F$. oxysporum f. sp. ciceris (Padwick) Matuo \& K. Sato. The inoculated plants were maintained in the greenhouse at 25 to $28^{\circ} \mathrm{C}$ and inspected periodically for symptom development and appearance of sporulating layers on the stems. Noninoculated control plants were maintained under the same conditions.

\section{RESULTS}

Occurrence of conidia of $\boldsymbol{F}$. oxysporum f. sp. lycopersici on tomato stems. Cherry tomato plants of the Fusarium wilt-susceptible cultivar BR 139 showing symptoms of wilting and partial desiccation were observed in 1992 in a greenhouse at Nir-Zevi in the central part of Israel. In this greenhouse, the same susceptible cultivar had been grown for three successive years without soil disinfestation, a practice that apparently led to disease buildup, reaching more than $50 \%$ diseased plants in certain spans of the greenhouse. Some plants that were at advanced stages of disease development and various stages of desiccation had their lower stems covered with a light-pink layer ranging in length from a few to $20 \mathrm{~cm}$ (Fig. 1). Light and scanning electron microscopic examination revealed that this layer consisted mainly of masses of macroconidia (Fig. 2). Sporulation on tomato stems is considered a typical sign of $F$. oxysporum f. sp. radicis-lycopersici $(16,29)$. However, typical Fusarium wilt symptoms such as leaf yellowing and xylem discoloration in the lower and upper stem parts to a height of $150 \mathrm{~cm}$ or more also were observed on these plants. The root system of most plants looked healthy, and no lesions were noticed there or on the crown. Later in the season, more plants became desiccated, and their stems were covered with conidial masses. Monoconidial isolates of $F$. oxysporum, obtained from inner stem tissues of seven plants, were vegetatively compatible with nit mutant testers of VCG 0030 of $F$. oxysporum f. sp. lycopersici. Like-

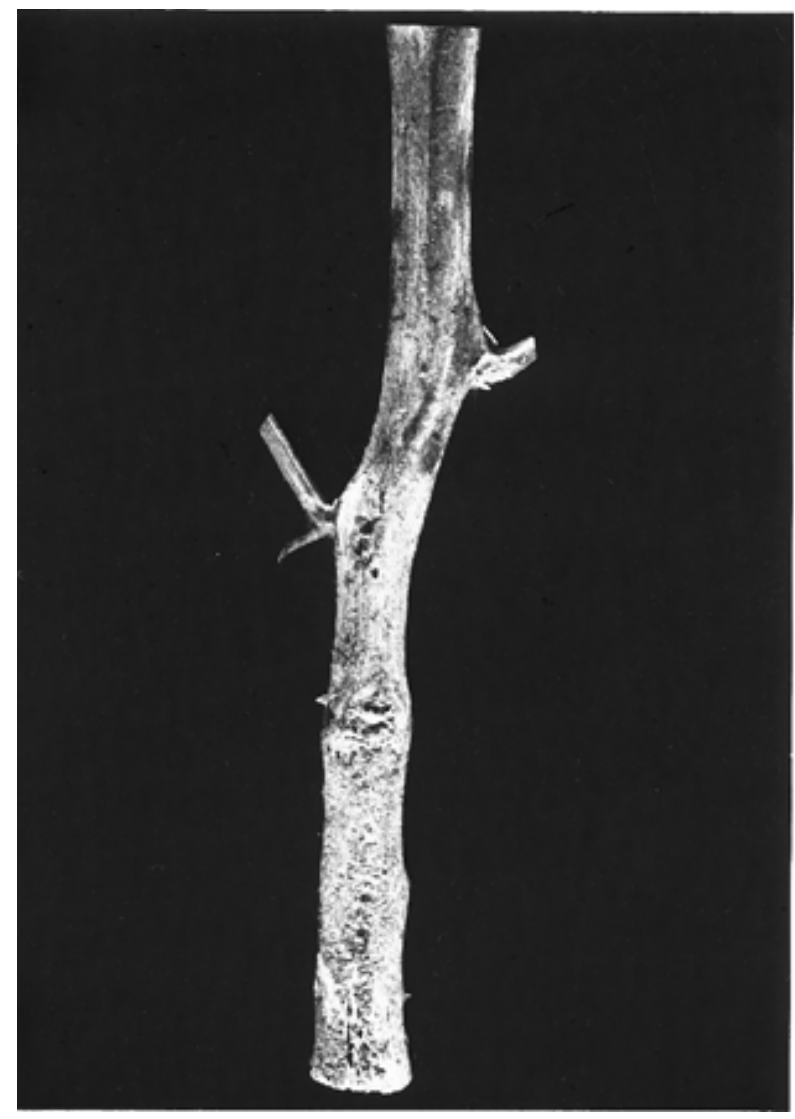

Fig. 1. Sporulation of Fusarium oxysporum f. sp. lycopersici on the lower stem surface of a diseased cherry tomato plant (natural infection). wise, all seven isolates were identified as $F$. oxysporum f. sp. lycopersici (race 1) when inoculated on tomato seedlings. For comparison, three isolates previously obtained from this greenhouse and identified as $F$. oxysporum f. sp. radicis-lycopersici by pathogenicity and VCG tests (25) caused typical crown and root rot symptoms on inoculated seedlings.

In subsequent years, plants showing wilt and xylem discoloration along with sporulating layers on the stems, similar to those found in Nir-Zevi, were found in other greenhouses located in different regions of Israel (Table 1), separated by a maximum distance of $150 \mathrm{~km}$. The sporulating layer was found mainly on stems of slowly desiccating plants in an advanced stage of disease development and was restricted to the lower part of the stem, usually extending 10 to $15 \mathrm{~cm}$ in length, occasionally up to $25 \mathrm{~cm}$. Microscopic examination revealed that 80 to $95 \%$ of the spores were macroconidia, the rest being microconidia. In a few cases, especially when the sporulating layer had a whitish appearance, the proportion of microconidia was higher, about 50 to $90 \%$. F oxysporum was isolated from upper stem tissues of 38 plants from seven greenhouses (including Nir-Zevi) and used for pathogen identification (Table 2). Vegetative compatibility constituted the

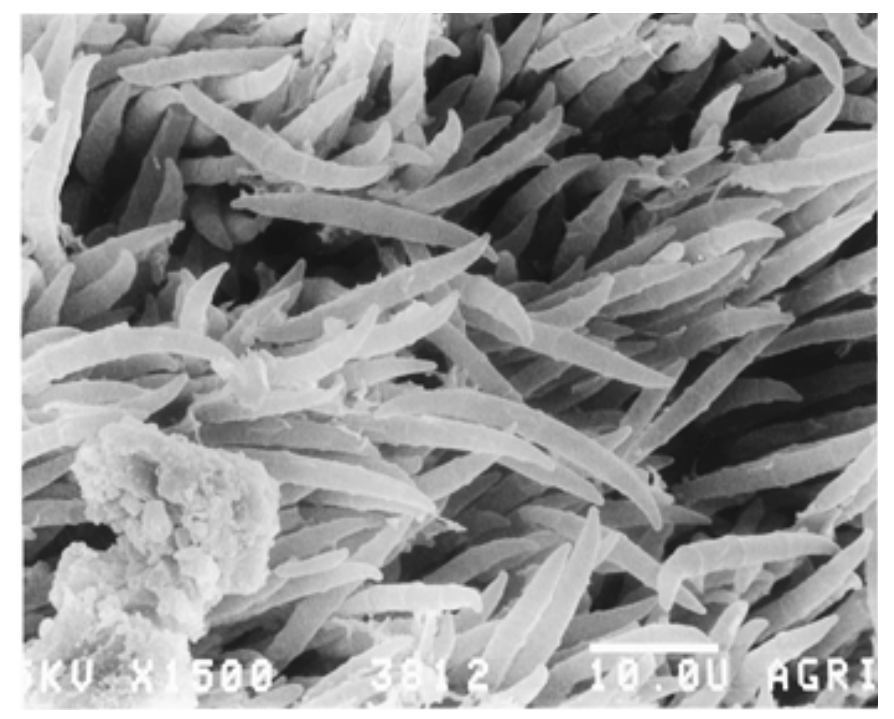

Fig. 2. Scanning electron micrograph of macroconidia of Fusarium oxysporum f. sp. lycopersici on the stem surface of a diseased cherry tomato plant. Bar $=10 \mu \mathrm{m}$.

TABLE 1. Greenhouses in which sporulating layers of Fusarium oxysporum f. sp. lycopersici have been observed on the lower stems of cherry tomato 'BR 139' plants

\begin{tabular}{|c|c|c|c|c|}
\hline Region & Greenhouse site & Year & Disease incidence $^{\mathrm{a}}$ & Race $^{b}$ \\
\hline North & $\begin{array}{l}\text { Kefar-Hess } \\
\text { Hanniel } \\
\text { Yamma }^{c}\end{array}$ & $\begin{array}{l}1993 \\
1994 \\
1994 \\
1995\end{array}$ & $\begin{array}{l}\text { High } \\
\text { High } \\
\text { Moderate } \\
\text { Moderate }\end{array}$ & $\begin{array}{c}1 \& 2 \\
1 \\
1 \& 2 \\
1\end{array}$ \\
\hline Center & $\begin{array}{l}\text { Nir-Zevic } \\
\text { Gan-Soreq }\end{array}$ & $\begin{array}{l}1992 \\
1994 \\
1995 \\
1996 \\
1996\end{array}$ & $\begin{array}{l}\text { High } \\
\text { Moderate } \\
\text { High } \\
\text { High } \\
\text { Low }\end{array}$ & $\begin{array}{l}1 \\
1 \\
1 \\
1 \\
1\end{array}$ \\
\hline South & $\begin{array}{l}\text { Mivtahim } \\
\text { Ammioz } \\
\text { Yesha }\end{array}$ & $\begin{array}{l}1994 \\
1995 \\
1995 \\
1995\end{array}$ & $\begin{array}{l}\text { Low } \\
\text { Low } \\
\text { High } \\
\text { Low }\end{array}$ & $\begin{array}{l}1 \\
1 \\
1 \\
1\end{array}$ \\
\hline
\end{tabular}

a Disease incidence refers to greenhouse spans that were surveyed. Low $=$ up to $10 \%$ diseased plants; moderate $=11$ to $40 \%$ diseased plants; and high $=$ $>40 \%$ diseased plants.

b All isolates belonged to vegetative compatibility group 0030.

${ }^{c}$ Greenhouses with a previous record of Fusarium crown and root rot. 
principal criterion for distinguishing between $F$. oxysporum $\mathrm{f}$. sp. lycopersici and $F$. oxysporum f. sp. radicis-lycopersici. All 38 isolates belonged to VCG 0030 of $F$. oxysporum f. sp. lycopersici, and nine representatives were not compatible with any tester of the local VCGs of $F$. oxysporum f. sp. radicis-lycopersici (25). Pathogenicity tests of five representatives from three greenhouses confirmed their identification as $F$. oxysporum f. sp. lycopersici, four being race 1 and one race 2 .

Identification of macroconidial isolates of $\boldsymbol{F}$. oxysporum by vegetative compatibility and virulence tests. The possibility that the occurrence of wilt symptoms along with sporulation on stems of the same plant resulted from coinfection by both the Fusarium wilt pathogen and the crown and root rot pathogen was investigated in six greenhouses (Table 3). In the Gan-Soreq greenhouse, $54 \mathrm{~F}$. oxysporum isolates were obtained from individual macroconidia from the stem surfaces of seven plants (2 to 15 macroconidia/plant). All macroconidial isolates belonged to VCG 0030 of $F$. oxysporum $\mathrm{f}$. sp. lycopersici, providing strong evidence for the hypothesis that these plants were colonized by this pathogen alone; representatives from four plants were identified as race 1 . In a similar study in the Yamma greenhouse, 159 macroconidial isolates from 24 plants ( 2 to 11 macroconidia/plant) (Table 3 ) and eight isolates from the upper stems belonged to VCG 0030 of $F$. oxysporum f. sp. lycopersici. Seven macroconidial isolates from one plant (plant no. 14) all belonged to VCG 0090II of $F$. oxysporum f. sp. radicis-lycopersici. In pathogenicity tests of 34 macroconidial isolates from 21 plants, all of them were identified as race 1 of $F$. oxysporum f. sp. lycopersici. All macroconidial isolates from stem surfaces of cherry tomatoes from the four other greenhouses were uniformly characterized as belonging to VCG 0030 of $F$. oxysporum f. sp. lycopersici (Table 3). In conclusion, out of 296 macroconidial isolates from 47 plants in six greenhouses, 289 isolates from 46 plants were identified as belonging to VCG 0030 of $F$. oxysporum f. sp. lycopersici, and 45 representatives were confirmed as race 1; the remaining seven from one plant were F. oxysporum f. sp. radicis-lycopersici. The macroconidial isolates of the pathogen originating from the sporulating layer did not differ from isolates originating from discolored xylem tissues in either their morphology or the symptoms they incited in pathogenicity tests.
Density, infectivity, and survival of conidia from stem surfaces. Stems with sporulating layers were collected from greenhouses Gan-Soreq, Yamma, and Ammioz. Twenty-four stem pieces originating from nine plants were used to enumerate conidia on the stem surfaces. The number was variable and ranged from 0.7 $\times 10^{6}$ to $144 \times 10^{6}$ conidia/cm of stem. Thus, the total number found on a diseased plant with a typical sporulating layer of $10 \mathrm{~cm}$ could range from $7 \times 10^{6}$ to $1.44 \times 10^{9}$ conidia/plant. Germination rate of the conidia was above $85 \%$.

The capacity of macroconidia naturally formed on stem surfaces to incite disease in tomato seedlings was assessed by using them directly as inoculum. When $5 \times 10^{5}$ or $10^{6}$ macroconidia/ml were used to inoculate 'Marmande' seedlings, disease incidence was $100 \%$. In a second experiment, disease percentages were 68 and $54 \%$ at inoculum concentrations of $10^{4}$ and $5 \times 10^{4}$ macroconidia/ml, respectively. The corresponding values for inoculation with inoculum grown on CDM were 86 and $71 \%$ in the first experiment, and 57 and $54 \%$ in the second. All 'Rehovot 13' seedlings inoculated with similar concentrations of both types of inocula remained healthy, thus confirming the identity of the isolates as race 1 .

Survival of the macroconidia was evaluated by storing tomato stems covered with macroconidia under dry conditions at $5^{\circ} \mathrm{C}$ or at room temperature $\left(18\right.$ to $\left.24^{\circ} \mathrm{C}\right)$ and assessing germination rate periodically. The initial germination of $90 \%$ declined to 67,53 , 19 , and $0.06 \%$ after $70,132,200$, and 360 days, respectively, at room temperature, while the corresponding values at $5^{\circ} \mathrm{C}$ were 78 , 79,79 , and $70 \%$.

Rhizosphere studies. Rhizosphere samples were taken from three different locations in the Gan-Soreq greenhouse to enumerate Fusarium. The population of $F$. oxysporum ranged from 15,600 to $41,200 \mathrm{CFU} / \mathrm{g}$ of rhizosphere soil. Out of 47 representative colonies (15 or 16 colonies/sample), 45 belonged to VCG 0030 and race 1 of $F$. oxysporum f. sp. lycopersici (Table 2). The remaining two rhizosphere isolates were not compatible with either VCG 0030 of $F$. oxysporum f. sp. lycopersici or the five local VCGs of $F$. oxysporum f. sp. radicis-lycopersici (25), nor were they pathogenic to tomato seedlings. The calculated population of F. oxysporum f. sp. lycopersici ranged from 15,600 to 35,700 $\mathrm{CFU} / \mathrm{g}$ of soil.

TABLE 2. Vegetative compatibility and pathogenicity of Fusarium oxysporum from the inner stem tissue and rhizosphere of diseased cherry tomato plants showing sporulation on the lower stems and from other sources in the greenhouse

\begin{tabular}{|c|c|c|c|c|c|c|c|}
\hline \multirow{3}{*}{ Source } & \multirow{3}{*}{ Site } & \multicolumn{6}{|c|}{ Number of isolates tested for } \\
\hline & & \multicolumn{3}{|c|}{ Vegetative compatibility } & \multicolumn{3}{|c|}{ Pathogenicity } \\
\hline & & $\begin{array}{l}\text { F. oxysporum } \\
\text { f. sp. lycopersici } i^{\text {a }}\end{array}$ & $\begin{array}{l}\text { F. oxysporum } \mathrm{f} . \mathrm{sp} . \\
\text { radicis-lycopersici }{ }^{\mathrm{b}}\end{array}$ & F. oxysporum ${ }^{\mathrm{c}}$ & \multicolumn{2}{|c|}{ F. oxysporum f. sp. lycopersici } & $\begin{array}{l}\text { F. oxysporum } \mathrm{f} \text {. sp. } \\
\text { radicis-lycopersici }\end{array}$ \\
\hline \multirow[t]{4}{*}{ Plant $^{\mathrm{d}}$} & Nir-Zevi & $11 / 11^{\mathrm{e}}$ & $0 / 5$ & & $7 / 7$ & $0 / 7$ & $0 / 7$ \\
\hline & Kefar-Hess & $5 / 5$ & $0 / 1$ & & $3 / 3$ & $0 / 3$ & ${ }^{\mathrm{f}}$ \\
\hline & Gan-Soreq & $4 / 4$ & $\ldots$ & & $1 / 1$ & $0 / 1$ & $\ldots$ \\
\hline & Yashresh & $2 / 2$ & $0 / 2$ & & $\ldots$ & $\ldots$ & $\ldots$ \\
\hline Rhizosphere ${ }^{g}$ & Gan-Soreq & $45 / 47$ & $0 / 2$ & $2 / 47$ & $2 / 2$ & $0 / 2$ & $\ldots$ \\
\hline Strings ${ }^{\mathrm{h}}$ & Yamma & $10 / 10$ & $\ldots$ & & $8 / 8$ & $0 / 8$ & $\ldots$ \\
\hline Walls ${ }^{\mathrm{h}}$ & Gan-Soreq & $4 / 4$ & $\cdots$ & & $2 / 2$ & $0 / 2$ & $\begin{array}{l}\cdots \\
\cdots\end{array}$ \\
\hline \multirow[t]{2}{*}{ Air-trapping ${ }^{\mathrm{h}}$} & Gan-Soreq & $33 / 41$ & $0 / 10$ & $8 / 41$ & $15 / 15$ & $0 / 15$ & $0 / 2$ \\
\hline & Yamma & $10 / 10$ & $\ldots$ & & $1 / 1$ & $0 / 1$ & $0 / 1$ \\
\hline
\end{tabular}

a Vegetative compatibility group (VCG) 0030 .

${ }^{\mathrm{b}}$ Isolates tested against testers of local VCGs 0090, 0091, 0092, 0093, and 0096.

c Vegetatively self-compatible isolates of $F$. oxysporum not compatible with any of the testers.

${ }^{\mathrm{d}}$ One monoconidial isolate per plant.

e (Isolates in this category)/(Isolates tested).

${ }^{\mathrm{f}}$ Not tested.

$\mathrm{g}$ Isolates obtained from rhizospheres of three plants, growing as individual colonies on dilution plates and not single-spored.

${ }^{\mathrm{h}}$ Individual colonies, not single-spored. 
Trapping of airborne propagules and their presence on greenhouse components. Fusarium propagules were trapped on four separate occasions in three greenhouses (Table 4). Out of 60 F. oxysporum colonies growing from trapped propagules, 52 belonged to VCG 0030 of $F$. oxysporum $\mathrm{f}$. sp. lycopersici, and all 24 representatives tested were identified as race 1 (Table 2). None of the tested colonies belonged to $F$. oxysporum f. sp. radicislycopersici. The average number of trapped propagules of $F$. oxysporum f. sp. lycopersici ranged from 0 to 4.5 per plate.

$F$. oxysporum was also isolated from plastic strings serving as tomato-plant support in the Yamma and Ammioz greenhouses.

TABLE 3. Vegetative compatibility and pathogenicity of Fusarium oxysporum isolates originating from single macroconidia on lower stem surfaces of individual cherry tomato plants

\begin{tabular}{|c|c|c|c|c|c|}
\hline \multirow[b]{3}{*}{ Site } & \multirow[b]{3}{*}{ Plant no. } & \multicolumn{4}{|c|}{ Number of isolates tested for } \\
\hline & & \multicolumn{2}{|c|}{ Vegetative compatibility } & \multicolumn{2}{|c|}{ Pathogenicity } \\
\hline & & $\begin{array}{l}\text { F. oxysporum } \\
\text { f. sp. } \\
\text { lycopersici }^{\mathrm{a}}\end{array}$ & $\begin{array}{l}\text { F. oxysporum } \\
\text { f. sp. radicis- } \\
\text { lycopersici }\end{array}$ & $\begin{array}{l}\text { F. oxysporum } \\
\text { f. sp. } \\
\text { lycopersici }^{\mathrm{c}}\end{array}$ & $\begin{array}{l}\text { F. oxysporum } \\
\text { f. sp. radicis- } \\
\text { lycopersici }\end{array}$ \\
\hline \multirow[t]{7}{*}{ Gan-Soreq } & 1 & $10 / 10^{\mathrm{d}}$ & $0 / 2$ & $1 / 1$ & $0 / 1$ \\
\hline & 2 & $15 / 15$ & $0 / 2$ & $\ldots .{ }^{\mathrm{e}}$ & $\ldots$ \\
\hline & 3 & $9 / 9$ & $0 / 2$ & $\ldots$ & $\ldots$ \\
\hline & 4 & $10 / 10$ & $0 / 2$ & $\ldots$. & $\ldots$ \\
\hline & 5 & $4 / 4$ & $\ldots$ & $1 / 1$ & $0 / 1$ \\
\hline & 6 & $4 / 4$ & $\ldots$ & $1 / 1$ & $\ldots$. \\
\hline & 7 & $2 / 2$ & $\ldots$ & $1 / 1$ & $\ldots$ \\
\hline \multirow[t]{26}{*}{ Yamma } & 8 & $4 / 4$ & $\ldots$ & $1 / 1$ & $0 / 1$ \\
\hline & 9 & $10 / 10$ & $\ldots$ & $1 / 1$ & $0 / 1$ \\
\hline & 10 & $11 / 11$ & $\ldots$ & $\ldots$ & $\ldots$ \\
\hline & 11 & $6 / 6$ & $\ldots$ & $\ldots$ & $\ldots$ \\
\hline & 12 & $10 / 10$ & $\ldots$ & $\ldots$ & $\ldots$ \\
\hline & 13 & $5 / 5$ & $\ldots$ & $1 / 1$ & $0 / 1$ \\
\hline & 14 & $0 / 7$ & $7 / 7$ & $\ldots$ & $\ldots$. \\
\hline & 15 & $8 / 8$ & $0 / 2$ & $2 / 2$ & $\ldots$ \\
\hline & 16 & $8 / 8$ & $0 / 8$ & $1 / 1$ & $\ldots$ \\
\hline & 17 & $8 / 8$ & $0 / 8$ & $1 / 1$ & $\ldots$ \\
\hline & 18 & $7 / 7$ & $0 / 7$ & $2 / 2$ & $\ldots$ \\
\hline & 19 & $7 / 7$ & $0 / 7$ & $1 / 1$ & $\ldots$ \\
\hline & 20 & $6 / 6$ & $0 / 6$ & $2 / 2$ & $\ldots$ \\
\hline & 21 & $7 / 7$ & $0 / 7$ & $2 / 2$ & $\ldots$ \\
\hline & 22 & $6 / 6$ & $0 / 6$ & $2 / 2$ & $\ldots$ \\
\hline & 23 & $6 / 6$ & $0 / 6$ & $1 / 1$ & $\ldots$ \\
\hline & 24 & $7 / 7$ & $0 / 7$ & $2 / 2$ & $\ldots$ \\
\hline & 25 & $8 / 8$ & $0 / 8$ & $2 / 2$ & $\ldots$ \\
\hline & 26 & $2 / 2$ & $0 / 2$ & $2 / 2$ & $\ldots$ \\
\hline & 27 & $6 / 6$ & $0 / 6$ & $2 / 2$ & $0 / 1$ \\
\hline & 28 & $6 / 6$ & $0 / 6$ & $2 / 2$ & $\ldots$ \\
\hline & 29 & $6 / 6$ & $0 / 6$ & $2 / 2$ & $\ldots$ \\
\hline & 30 & $6 / 6$ & $0 / 6$ & $1 / 1$ & $\ldots$ \\
\hline & 31 & $3 / 3$ & $0 / 3$ & $2 / 2$ & $\ldots$ \\
\hline & 32 & $6 / 6$ & $0 / 6$ & $2 / 2$ & $0 / 1$ \\
\hline & 33 & $6 / 6$ & $0 / 1$ & $\ldots$ & $0 / 1$ \\
\hline Yesha & 34 & $7 / 7$ & $0 / 1$ & $1 / 1$ & $0 / 1$ \\
\hline Mivtahim & 35 & $7 / 7$ & $0 / 1$ & $\ldots$ & $\ldots$ \\
\hline \multirow[t]{6}{*}{ Ammioz } & 36 & $7 / 7$ & $0 / 1$ & $\ldots$ & $\ldots$ \\
\hline & 37 & $8 / 8$ & $0 / 1$ & $1 / 1$ & $0 / 1$ \\
\hline & 38 & $7 / 7$ & $0 / 2$ & $\ldots$ & $\ldots$ \\
\hline & 39 & $7 / 7$ & $0 / 1$ & $\ldots$ & $\ldots$ \\
\hline & 40 & $8 / 8$ & $0 / 1$ & $\ldots$ & $\ldots$ \\
\hline & 41 & $4 / 4$ & $\ldots$ & $1 / 1$ & $0 / 1$ \\
\hline \multirow{6}{*}{ Yashresh } & 42 & $3 / 3$ & $\ldots$ & $\ldots$ & $\ldots$ \\
\hline & 43 & $4 / 4$ & $\ldots$ & $\ldots$ & $\ldots$ \\
\hline & 44 & $1 / 1$ & $0 / 1$ & $\ldots$ & $\ldots$ \\
\hline & 45 & $2 / 2$ & $0 / 2$ & $\ldots$ & $\ldots$ \\
\hline & 46 & $3 / 3$ & $\ldots$ & $1 / 1$ & $0 / 1$ \\
\hline & 47 & $2 / 2$ & $\ldots$ & $3 / 3$ & $0 / 1$ \\
\hline Total & 47 & $289 / 296$ & $7 / 134$ & $45 / 45$ & $0 / 13$ \\
\hline
\end{tabular}

a Vegetative compatibility group (VCG) 0030.

${ }^{\mathrm{b}}$ Isolates tested against testers of local VCGs 0090, 0091, 0092, 0093, and 0096. All isolates from plant no. 14 belonged to VCG 0090II.

${ }^{\mathrm{c}}$ Race 1.

d (Isolates in this category)/(Isolates tested).

e Not tested.
Contamination of strings by $F$. oxysporum f. sp. lycopersici ranged from 0.5 to $5 \mathrm{CFU} / \mathrm{cm}$. Each colony may have represented more than one propagule. F. oxysporum also was recovered from greenhouse walls. All tested isolates from strings and walls belonged to VCG 0030 and race 1 of $F$. oxysporum $\mathrm{f}$. sp. lycopersici (Table 2).

Simulation of conidial production on surfaces of plant stems. In an attempt to reproduce the sporulating layer on stem surfaces under experimental greenhouse conditions, tomato plants were inoculated with isolates of two races of $F$. oxysporum f. sp. lycopersici. The possibility that the sporulating layer was formed by a special variant of $F$. oxysporum f. sp. lycopersici was investigated by inoculating two tomato cultivars susceptible to race 1 with macroconidial isolates in parallel to reference $F$. oxysporum f. sp. lycopersici isolates. In the first experiment with 111 plants (Table 5), typical sporulating layers formed on the stems of $40 \%$ of the diseased 'BR 139' plants and on $65 \%$ of the diseased 'Marmande' plants inoculated with race 1. Disease symptoms usually appeared 30 to 50 days after inoculation, and the sporulating layer became visible on the diseased plants 10 to 25 days later, especially on desiccated plants. The sporulating layer on the stem had a yellowish color and resembled the phenomenon observed in commercial greenhouses. In most cases, the sporulating layer consisted of 70 to $99 \%$ macroconidia, the remainder being microconidia, while, in a few cases, the layer appeared whitish and consisted mainly of microconidia. Covering the lower stem of diseased plants with a polyethylene sheet along with moistened cotton wool close to, but not contacting, the stems resulted in the formation of a thick sporulating layer within 24 to $72 \mathrm{~h}$. All isolates of race 1, regardless of their origin, induced the formation of sporulating layers on both cultivars, whereas the race 2 reference isolate FOL-1295 did not induce sporulation on any of the inoculated plants. In the second experiment, additional isolates were examined (Table 5), and sporulation was observed on the stems of $87 \%$ of the plants of both cultivars inoculated with race 1. Isolate FOL-1295 again did not form such a layer on inoculated plants, whereas two other isolates of race 2 did form it on $75 \%$ of the inoculated plants. Microscopic examination of the stems of 'Marmande' plants inoculated with FOL-1295 did not reveal the presence of conidia. When the stems of these plants were covered with a polyethylene sheet and moistened cotton wool, a thin whitish layer with a few microconidia appeared on only one out of seven plants.

In experiment 1 , the noninoculated plants (10 plants of each cultivar) remained healthy except for one 'Marmande' plant from which a pathogenic isolate (race 1) was subsequently isolated. In experiment 2, eight noninoculated plants of each cultivar were included, along with an additional eight noninoculated plants around which the soil surface had been covered with a 2-cm layer of vermiculite. One noninoculated 'BR 139' plant, in which the soil had not been covered with vermiculite, became diseased.

The potential of additional formae speciales of $F$. oxysporum to form a sporulating layer on the stems of their respective host

TABLE 4. Airborne propagules of Fusarium oxysporum and F. oxysporum $\mathrm{f}$. sp. lycopersici (race 1) in three greenhouses of cherry tomato ${ }^{\mathrm{a}}$

\begin{tabular}{|c|c|c|c|c|c|}
\hline \multirow[b]{3}{*}{ Greenhouse $^{b}$} & \multirow{3}{*}{$\begin{array}{l}\text { Spans } \\
\text { tested } \\
\text { (no.) }\end{array}$} & \multirow[b]{3}{*}{ Sampling date } & \multicolumn{3}{|c|}{ Colonies per plate } \\
\hline & & & \multirow{2}{*}{$\begin{array}{l}\text { F. oxysporum } \\
\text { average }\end{array}$} & \multicolumn{2}{|c|}{$\begin{array}{c}\text { F. oxysporum } \\
\text { f. sp. lycopersici }\end{array}$} \\
\hline & & & & Average & Range $^{\mathrm{c}}$ \\
\hline Gan-Soreq & 9 & 28 December 1994 & 1.36 & 0.78 & $0.1-2.8$ \\
\hline Gan-Soreq & 5 & 30 July 1995 & 2.98 & 2.74 & $0-4.5$ \\
\hline Yamma & 5 & 22 January 1995 & 0.28 & 0.28 & $0-0.5$ \\
\hline Ammioz & 5 & 13 December 1995 & 1.62 & 1.3 & $0.8-1.8$ \\
\hline
\end{tabular}


plants was examined under experimental greenhouse conditions, similar to the tomato experiments. Two inoculation experiments were conducted with muskmelon and eggplant, and single experiments were conducted with cucumber, chickpea, and cotton. Disease incidence ranged from 80 to $100 \%$. In the various experiments, a sporulating layer formed on 50 to $80 \%$ of the diseased plants (6 to 12 plants in each experiment). The sporulation was usually visible 10 to 30 days after disease symptom appearance, except in cotton, in which it was visible after 20 to 50 days. In cotton, a thin sporulating layer also formed on desiccating stem apices and leaf petioles, especially leaves that had naturally dropped off the plant. Most of the spores were macroconidia.

\section{DISCUSSION}

We have shown that $F$. oxysporum f. sp. lycopersici can form conidia on the surfaces of diseased tomato stems. Additionally, we have strong evidence to suggest that these conidia can become airborne and result in the spread of this important pathogen. This phenomenon, which is typical of above-ground pathogens but considered uncommon with soilborne pathogens, has not been previously reported with $F$. oxysporum $\mathrm{f}$. sp. lycopersici. On the other hand, conidial formation on tomato stems is a typical sign of $F$. oxysporum f. sp. radicis-lycopersici, which is also a soilborne pathogen. Above-ground conidial formation by $F$. oxysporum f. sp. lycopersici raises questions concerning the conditions favoring conidial formation and its epidemiological consequences.

The vegetative compatibility (heterokaryon) test, using nit mutants, has proven to be a powerful tool in distinguishing between $F$. oxysporum f. sp. lycopersici and $F$. oxysporum f. sp. radicis-lycopersici in local populations of these pathogens in tomato fields and greenhouses. In Israel, all isolates of $F$. oxysporum f. sp. lycopersici (races 1 and 2) tested to date belong to VCG 0030 (21), represented by nit testers FOL-R and FOL-M. In F. oxysporum f. sp. radicis-lycopersici, five VCGs (and several subgroups) have been found that are represented by eight pairs of nit mutant testers (25). Vegetative compatibility has never been found between $F$. oxysporum f. sp. lycopersici and $F$. oxysporum f. sp. radicis-lycopersici. Since its results have been validated by pathogenicity tests $(7,8,15,22,23,25)$, the vegetative compatibility test offers a dependable, convenient alternative that requires considerably fewer resources and no greenhouse facilities. Moreover, it is accurate, highly reproducible, and independent of factors affecting host response to inoculation (e.g., temperature, light, growth substrate, and cultivar), which may lead to uncertain results. With the occurrence of unusual phenomena, this test is particularly useful in resolving ambiguity concerning the identity of the causal agents.

Of the 296 macroconidial isolates from 47 plants at six sites, 289 from 46 plants were identified as belonging to VCG 0030 of F. oxysporum f. sp. lycopersici, and 45 representatives were confirmed as race 1 in pathogenicity tests (Table 3 ). Macroconidia of F. oxysporum f. sp. radicis-lycopersici were found on one plant only (plant no. 14) (Table 3), and all of those tested uniformly belonged to VCG 0090II of this pathogen. These results show that both wilting and sporulation on stems of cherry tomatoes were incited by $F$. oxysporum f. sp. lycopersici, thus ruling out the possibility of coinfection with $F$. oxysporum $\mathrm{f}$. sp. radicis-lycopersici. The exclusive recovery from the rhizosphere, the plastic walls, the plastic strings, and airborne propagules of $F$. oxysporum $\mathrm{f}$. sp. lycopersici further supports its role as the only $F$. oxysporum pathogen responsible for the disease in the studied greenhouses. The macroconidial isolates did not differ from other race 1 isolates in morphology, vegetative compatibility, or pathogenicity. Sporulation occurred on diseased tomato plants following artificial inoculation with the reference isolate FOL-1 (obtained from the discolored xylem of a diseased plant 12 years ago), as well as with macroconidial isolates (Table 5).
Conidial formation (mainly macroconidia similar to those found under natural conditions) was reproduced in two experiments under controlled conditions with the two tested tomato cultivars. Sporulation was induced on the stems by nine isolates belonging to two races regardless of their source, namely, from discolored xylem tissue or from macroconidia naturally formed on tomato stems. The race 2 reference isolate FOL-1295 did not form conidia on stems of either cultivar, although two other isolates of race 2 did. We noticed that conidial formation was less pronounced on plants in which disease development was rapid, with quick desiccation. Thus, conidial formation may be associated with the disintegration of the plant tissues, thereby exposing the pathogen colonizing the vascular tissue to ambient conditions. Conidial formation has been observed on cracks of stem cortical tissues of cucurbits infected with pathogenic F. oxysporum (3,10; M. Cirulli, personal communication). Apparently, a situation favoring sporulation was not achieved when isolate FOL-1295 served as inoculant. In commercial greenhouses, conidial formation was only observed on 'BR 139'. However, since 'Marmande' also responded with conidial formation on the stems (Table 5), this greenhouse observation should not be attributed to the uniqueness of 'BR 139', but to the fact that it is the only Fusarium wilt-susceptible cultivar currently grown in greenhouses in Israel.

Based on the vegetative compatibility, pathogenicity, and simulation tests, we conclude that above-ground sporulation on tomato stems in the surveyed greenhouses was caused by common strains of $F$. oxysporum f. sp. lycopersici, which do not differ from standard strains of this pathogen. Fusarium sporulation on stems may be enhanced by certain agricultural practices, such as drip irrigation providing a constant humid environment near the stem base.

Fusarium wilt of tomatoes has been recognized for over 100 years (35), but, except for one statement (12) (kindly brought to our attention by J. Fletcher), we did not find any reports on aboveground sporulation of this pathogen. Nevertheless, the phenomenon has been observed by researchers who kindly shared their observations with us via personal communications: from Belgium (A. Vanachter), Italy (M. Cirulli), Florida (D. O. Chellemi), and the United Kingdom (J. Fletcher). It is not known whether this phenomenon has occurred but has been overlooked in the past, or whether it is due to recent changes in certain practices. Besides

TABLE 5. Sporulation of Fusarium oxysporum f. sp. lycopersici on stems of artificially inoculated tomato plants

\begin{tabular}{|c|c|c|c|c|c|c|c|}
\hline \multirow[b]{2}{*}{ Exp. } & \multirow[b]{2}{*}{ Isolate } & \multirow[b]{2}{*}{ Race } & \multirow[b]{2}{*}{ Source ${ }^{a}$} & \multirow[b]{2}{*}{$\mathrm{CV}^{\mathrm{b}}$} & \multicolumn{3}{|c|}{ Number of plants } \\
\hline & & & & & Inoculated & Diseased & Sporulating \\
\hline \multirow[t]{12}{*}{1} & FOL-1 & 1 & DP & 139 & 10 & 10 & 3 \\
\hline & FOL-15A & 1 & $\mathrm{Mac}$ & 139 & 8 & 6 & 2 \\
\hline & FOL-32B & 1 & $\mathrm{Mac}$ & 139 & 10 & 10 & 6 \\
\hline & FOL-27 & 1 & $\mathrm{Mac}$ & 139 & 10 & 8 & 4 \\
\hline & FOL-19C & 1 & $\mathrm{Mac}$ & 139 & 10 & 8 & 2 \\
\hline & FOL-1295 & 2 & DP & 139 & 11 & 9 & 0 \\
\hline & FOL-1 & 1 & DP & M & 10 & 10 & 4 \\
\hline & FOL-15A & 1 & $\mathrm{Mac}$ & M & 8 & 4 & 1 \\
\hline & FOL-32B & 1 & Mac & M & 8 & 8 & 6 \\
\hline & FOL-27 & 1 & Mac & M & 8 & 8 & 7 \\
\hline & FOL-19C & 1 & Mac & M & 8 & 7 & 6 \\
\hline & FOL-1295 & 2 & DP & M & 10 & 9 & 0 \\
\hline \multirow[t]{7}{*}{2} & FOL-1 & 1 & DP & 139 & 8 & 8 & 7 \\
\hline & FOL-191 & 1 & Air & 139 & 8 & 8 & 7 \\
\hline & FOL-93H & 2 & DP & 139 & 8 & 8 & 6 \\
\hline & FOL-1 & 1 & DP & M & 8 & 8 & 7 \\
\hline & FOL-1295 & 2 & DP & M & 8 & 8 & 0 \\
\hline & FOL-93H & 2 & DP & M & 8 & 8 & 7 \\
\hline & FOL-841D & 2 & DP & M & 8 & 8 & 5 \\
\hline
\end{tabular}

a $\mathrm{DP}=$ originating from discolored vascular tissues of stems of wilt-diseased plants; Mac = originating from macroconidia from the stem surface of diseased tomato plants; and Air = originating from airborne propagule.

${ }^{\mathrm{b}} \mathrm{CV}=$ the cultivar that served for inoculation: $139=$ cherry tomato 'BR 139 ' and $\mathrm{M}=$ 'Marmande'. 
the well-known example of $F$. oxysporum f. sp. radicis-lycopersici, which is a cortical rather than a vascular pathogen and considered exceptional, other cases of above-ground sporulation by pathogenic forms of $F$. oxysporum have been reported including $\mathrm{f}$. sp. perniciosum on mimosa (26), f. sp. basilici on sweet basil $(14,33)$, f. sp. cyclaminis on cyclamen (36), f. sp. cucumerinum and f. sp. radicis-cucumerinum on cucumber $(3,10,34)$, and f. sp. vasinfectum on cotton (2). Sporulation on cotton also was observed by researchers at the beginning of this century (4). Similarly, in the current study, sporulation occurred on stems of muskmelon, cucumber, eggplant, and cotton plants artificially inoculated with their respective $F$. oxysporum pathogens, and chickpea sown in naturally infested soil. Abundant sporulation has been observed on stems of chickpea artificially inoculated with $F$. oxysporum $\mathrm{f}$. sp. ciceris (R. M. Jimenez-Diaz, personal communication). Taken together, these reports and observations suggest that the production of airborne inoculum by Fusarium wilt-inciting pathogens may be more common than previously thought, especially under favorable conditions.

The aerial dissemination of a soilborne pathogen has potential epidemiological consequences regarding its spread in space, survival in time, and disease management. Airborne propagules of $F$. oxysporum f. $\mathrm{sp}$. lycopersici were trapped at rates comparable with those reported for $F$. oxysporum f. sp. radicis-lycopersici (30) and $F$. oxysporum f. sp. basilici (14). These conidia have a pathogenic capacity, and their heavy production on the stems (over $10^{9}$ propagules/diseased plant) ensures that a certain fraction of the population survives. If conidial formation on petioles of dropped cotton leaves represents the situation in the field, this might have severe implications, since such leaves move over long distances.

Preplanting soil disinfestation is not sufficient to control a soilborne pathogen that has an airborne phase. A holistic, integrated management approach to deal with the different inoculum sources at various sites before, during, and after planting is essential (14). This approach should include measures such as the use of pathogen-free propagation material possibly loaded with biological or other control agents, manipulation of the environment to suppress sporulation, treating the already formed conidial masses on the stems with appropriate agents, removal of diseased plants prior to sporulation, proper greenhouse and personal hygiene and hardware sterilization as detailed elsewhere $(10,17)$, and sanitation of the greenhouse by space solarization (31) or chemical agents (10). Such an integrated approach has been very successful in controlling $F$. oxysporum f. sp. basilici on sweet basil (13), which also has an aerial dissemination phase. Aerial dissemination can be especially threatening when a new virulent race or pathotype is involved. Moreover, the immense amounts of conidia on diseased plants provide an additional population in which mutations can occur. It might be speculated that the rapid spread of race 2 of $F$. oxysporum f. sp. lycopersici in Florida in the 1960s (19) was connected with the production of airborne conidia, facilitated by the frequent rains in that area. Conidia of $F$. oxysporum f. sp. lycopersici have been recently observed on tomato stems in Florida (D. O. Chellemi, personal communication).

Soilborne pathogens are considered monocyclic in nature, namely, they have one life or disease cycle per growing season $(5,11)$, although exceptional cases of soilborne pathogens that exhibit polycyclic behavior have been reported $(11,28)$. The airborne conidia of $F$. oxysporum f. sp. lycopersici have the capacity to incite a disease, but it is not known whether they can function in the same season to induce disease in different plants under natural conditions. We assume that deposition on the soil of large numbers of airborne conidia disseminated throughout the season could create new foci of contamination. In the long run, this may be manifested as a polycyclic disease pattern or be considered polyetic (11). This further emphasizes the need to suppress conidial formation and dissemination. The above-ground dissemi- nation of soilborne pathogens raises new questions that need to be addressed in future investigations.

\section{ACKNOWLEDGMENTS}

This research was supported, in part, by the research fund of the Chief Scientist, Israeli Ministry of Agriculture. Contribution from the ARO, no. 2033-E, 1996 series. We thank E. Hadar, S. Erez, S. Lourie, O. Zeydan, R. Dakka, G. Elal, F. Kleitman, Y. Freiburg, Y. Messika, and N. Ganaim for their cooperation. We also thank our colleagues who shared with us their observations, experience, and ideas: C. Beckman, G. Bollen, R. N. Campbell, D. O. Chellemi, A. Cinar, M. Cirulli, P. Davet, J. Fletcher, W. R. Jarvis, R. M. Jimenez-Diaz, J. P. Jones, N. E. Malathrakis, A. Matta, H. Rattink, J. B. Ristaino, R. C. Rowe, D. Shtienberg, E. Tjamos, D. J. Vakalounakis, and A. Vanachter.

\section{LITERATURE CITED}

1. Beckman, C. H. 1987. The Nature of Wilt Diseases of Plants. The American Phytopathological Society, St. Paul, MN.

2. Bell, A. A. 1992. Verticillium wilt. Pages 87-126 in: Cotton Diseases. R. J. Hillocks, ed. C.A.B. International, Wallingford, United Kingdom.

3. Blancard, D., Lecoq, H., and Pitrat, M. 1994. A Colour Atlas of Cucurbit Diseases. Manson Publishing, London.

4. Bruehl, G. W. 1987. Soilborne Plant Pathogens. McMillan Publishing Co., London.

5. Campbell, C. L., and Madden, L. V. 1990. Introduction to Plant Disease Epidemiology. John Wiley \& Sons, New York.

6. Correll, J. C., Klittich, C. J. R., and Leslie, J. F. 1987. Nitrate nonutilizing mutants of Fusarium oxysporum and their use in vegetative compatibility tests. Phytopathology 77:1640-1646.

7. Correll, J. C., Puhalla, J. E., and Schneider, R. W. 1986. Indentification of Fusarium oxysporum f. sp. apii on the basis of colony size, virulence, and vegetative compatibility. Phytopathology 76:396-400.

8. Elias, K. S., and Schneider, R. W. 1991. Vegetative compatibility groups in Fusarium oxysporum f. sp. lycopersici. Phytopathology 81:159-162.

9. Elias, K. S., Zamir, D., Lichtman-Pleban, T., and Katan, T. 1993. Population structure of Fusarium oxysporum f. sp. lycopersici: Restriction fragment length polymorphisms provide genetic evidence that vegetative compatibility group is an indicator of evolutionary origin. Mol. PlantMicrobe Interact. 6:565-572.

10. Fletcher, J. T. 1984. Diseases of Greenhouse Plants. Longman Scientific \& Technical, London.

11. Fry, W. E. 1982. Principles of Plant Disease Management. Academic Press, Orlando, FL.

12. Gabe, H. L., and Knight, B. C. 1973. The occurrence of a second race of the tomato Fusarium wilt in the glasshouse. Pages 1013-1018 in: Proc. Br. Insectic. Fungic. Conf., 7th. Brighton, United Kingdom.

13. Gamliel, A., Katan, T., Yunis, H., and Katan, J. 1996. Fusarium wilt and crown rot of basil: Identification, epidemiology and control. (Abstr.) Phytoparasitica 24:143.

14. Gamliel, A., Katan, T., Yunis, H., and Katan, J. 1996. Fusarium wilt and crown rot of sweet basil: Involvement of soilborne and airborne inoculum. Phytopathology 86:56-62.

15. Hopkins, D. L., Lobinske, R. J., and Larkin, R. P. 1992. Selection for Fusarium oxysporum f. sp. niveum race 2 in monocultures of watermelon cultivars resistant to Fusarium wilt. Phytopathology 82:290-293.

16. Jarvis, W. R. 1988. Fusarium crown and root rot of tomatoes. Phytoprotection 69:49-64.

17. Jarvis, W. R. 1992. Managing Diseases in Greenhouse Crops. The American Phytopathological Society, St. Paul, MN.

18. Jarvis, W. R., and Shoemaker, R. A. 1978. Taxonomic status of $F u-$ sarium oxysporum causing foot and root rot of tomato. Phytopathology 68:1679-1680

19. Jones, J. P. 1966. Distribution of race 2 of Fusarium oxysporum f. lycopersici in Florida. Plant Dis. Rep. 50:707-708.

20. Katan, J., and Katan, T. 1992. Regional distribution of Fusarium crownand-root rot of tomato in Israel. (Abstr.) Phytoparasitica 20:227-228.

21. Katan, T. 1996. Vegetative-compatibility groups in populations of Fusarium oxysporum in Israel. (Abstr.) Phytoparasitica 24:139.

22. Katan, T., Gamliel, A., and Katan, J. 1996. Vegetative compatibility of Fusarium oxysporum from sweet basil in Israel. Plant Pathol. 45:656-661.

23. Katan, T., Hadar, E., and Katan, J. 1989. Vegetative compatibility of Fusarium oxysporum f. sp. dianthi from carnation in Israel. Plant Pathol. 38:376-381.

24. Katan, T., Shlevin, E., and Katan, J. 1996. Airborne inoculum of Fusarium oxysporum $\mathrm{f}$. sp. lycopersici in greenhouses of cherry tomatoes. (Abstr.) Phytoparasitica 24:143-144. 
25. Katan, T., Zamir, D., Sarfatti, M., and Katan, J. 1991. Vegetative compatibility groups and subgroups in Fusarium oxysporum f. sp. radicislycopersici. Phytopathology 81:255-262.

26. Phipps, P. M., and Stipes, R. J. 1976. Histopathology of mimosa infected with Fusarium oxysporum f. sp. perniciosum. Phytopathology 66:839843.

27. Puhalla, J. E. 1985. Classification of strains of Fusarium oxysporum on the basis of vegetative compatibility. Can. J. Bot. 63:179-183.

28. Ristaino, J. B. 1991. Influence of rainfall, drip irrigation, and inoculum density on the development of Phytophthora root and crown rot epidemics and yield in bell pepper. Phytopathology 81:922-929.

29. Rowe, R. C., and Farley, J. D. 1981. Strategies for controlling Fusarium crown and root rot in greenhouse tomatoes. Plant Dis. 65:107-112.

30. Rowe, R. C., Farley, J. D., and Coplin, D. L. 1977. Airborne spore dispersal and recolonization of steamed soil by Fusarium oxysporum in tomato greenhouses. Phytopathology 67:1513-1517.

31. Shlevin, E., Katan, J., Mahrer, Y., and Kritzman, G. 1995. Space solari- zation for sanitation of inocula of plant pathogens in the greenhouse structure. (Abstr.) Phytopathology 85:1209.

32. Singleton, L. L., Mihail, J. D., and Rush, C. M., eds. 1992. Methods for Research on Soilborne Phytopathogenic Fungi. The American Phytopathological Society, St. Paul, MN.

33. Uchida, J. Y., Kaddoka, C. Y., and Hamasaki, R. T. 1996. First report of Fusarium wilt of basil in Hawaii and foliar disease initiation. Plant Dis. $80: 105$.

34. Vakalounakis, D. J. 1996. Root and stem rot of cucumber caused by Fusarium oxysporum f. sp. radicis-cucumerinum f. sp. nov. Plant Dis. 80:313-316.

35. Walker, J. C. 1971. Fusarium Wilt of Tomato. Monograph 6. The American Phytopathological Society, St. Paul, MN

36. Woudt, L. P., Neuvel, A., Sikkema, A., van Grinsven, M. Q. J. M., de Milliano, W. A. J., Campbell, C. L., and Leslie, J. F. 1995. Genetic variation in Fusarium oxysporum from cyclamen. Phytopathology 85:13481355 . 